\title{
Aktivitas Antimalaria Daun Gempol (Nauclea orientalis (L.) L) terhadap Plasmodium falciparum
}

\author{
Antimalarial Activity from Gempol (Nauclea orientalis (L.) L) Leaves Againts Plasmodium \\ falciparum
}

Mery Budiarti*, Anshary Maruzy, Nengah Ratri RK, dan Endang Brotojoyo

Balai Besar Penelitian dan Pengembangan Tanaman Obat dan Obat Tradisional (B2P2TOOT), Badan Penelitian dan Pengembangan Kesehatan, Kementerian Kesehatan RI, Jln. Raya Lawu No. 11 Tawangmangu, Kabupaten Karanganyar 57792, Jawa Tengah, Indonesia

*Korespondensi Penulis : bsupriadi.mery@gmail.com

Submitted: 27-03-2020, Revised: 05-07-2020, Accepted: 12-08-2020

DOI: https://doi.org/10.22435/mpk.v30i2.3044

\begin{abstract}
Abstrak
Pemanfaatan batang gempol (Nauclea orientalis (L.) L) sebagai obat malaria telah terbukti secara empiris dan ilmiah. Kondisi tersebut mendorong terjadinya eksploitasi hingga dapat berujung pada kelangkaan bahan baku. Substitusi bagian tumbuhan sebagai bahan baku obat merupakan salah satu inovasi yang dapat dilakukan untuk keberlanjutan hidup spesies tumbuhan tersebut. Daun merupakan salah satu bagian tumbuhan yang sering digunakan sebagai bahan baku obat. Pemilihan daun sebagai bahan utama memiliki banyak kelebihan dibandingkan bagian lainnya. Penelitian terkait potensi bioaktif antimalaria daun Nauclea orientalis (L.) L hingga saat ini belum dipublikasikan. Oleh karena itu, penelitian ini bertujuan untuk menggali potensi aktivitas antimalaria daun sebagai alternatif subtitusi bagian batang. Ekstrak daun Nauclea orientalis (L.) L disiapkan dengan metode maserasi dengan etanol $96 \%$, kemudian dilakukan fraksinasi cair-cair bertingkat menggunakan pelarut heksana, etil asetat, dan metanol. Pengujian aktivitas antimalaria dilakukan secara in vitro terhadap Plasmodium falciparum 3D7 dan Kromatografi Lapis Tipis (KLT) untuk penapisan senyawa fitokimia pada masingmasing sampel. Pelarut heksana diketahui menghasilkan ekstrak paling optimum dengan rendemen $20 \%$. Aktivitas antimalaria fraksi heksana $\left(\mathrm{IC}_{50} 1,93 \mu \mathrm{g} / \mathrm{mL}\right)$ dan metanol $\left(\mathrm{IC}_{50} 3,91 \mu \mathrm{g} / \mathrm{mL}\right)$ yang tergolong dalam kategori 'sangat aktif, serta memiliki kecenderungan mampu bersaing dengan aktivitas klorokuin fosfat. Potensi aktivitas antimalaria pada kedua sampel tersebut dipengaruhi oleh kandungan senyawa alkaloid, steroid, flavonoid dan terpenoid yang telah banyak dikembangkan sebagai bahan aktif obat malaria. Hasil penelitian ini menunjukkan bahwa daun Nauclea orientalis (L.) L berpotensi untuk dikembangkan sebagai alternatif obat malaria.
\end{abstract}

Kata kunci: Nauclea orientalis (L.) L; antimalaria; Plasmodium falciparum; in vitro

\section{Abstract}

The use of gempol (Nauclea orientalis (L.) L) stem as a malaria medicine has been empirically and scientifically proven. This condition encourages exploitation which can lead to scarcity of raw materials. Substitution of plant parts as raw material for medicine is one of the innovations that can be done for the sustainability of the plant species. Leaves are one part of the plant that is often used as a raw material for medicine. The selection of leaves as the main ingredient has many advantages over other parts. Until now, research related to the antimalarial bioactive potential of $N$. orientalis $(\mathrm{L}$.) $\mathrm{L}$ leaves has not been published. Therefore, this study aimed to explore the potential for leaf antimalarial activity 
as an alternative to substitution of stem parts. The leaf extract of N. orientalis (L.) L was prepared by maceration method with $96 \%$ ethanol then fractionation was carried out in stage using hexane, ethyl acetate and methanol as solvents. Antimalarial activity testing was carried out in vitro against Plasmodium falciparum 3D7 and Thin Layer Chromatography (TLC) for screening phytochemical compounds in each sample. The hexane solvent was known to produce the most optimum extract by with a yield of $20 \%$. The antimalarial activity of the hexane $\left(I C_{50} 1.93 \mu \mathrm{g} / \mathrm{mL}\right)$ and methanol $\left(I C_{50} 3.91 \mu \mathrm{g} /\right.$ $m L$ ) fractions were classified as 'very active' and had a tendency to be able to compete with chloroquine phosphate activity. The potential for antimalarial activity in both samples was influenced by the content of alkaloids, steroids, flavonoids and terpenoids which had been developed as active ingredients for malaria drugs. The results of this study indicate that the leaves of Nauclea orientalis (L.) L have the potential to be developed as an alternative to malaria medicine.

Keywords: Nauclea orientalis (L.) L; antimalarial; Plasmodium falciparum; in vitro

\section{PENDAHULUAN}

Malaria termasuk salah satu penyakit yang menyebabkan tingginya angka kematian di dunia. Persebaran penyakit malaria meliputi negara-negara di wilayah beriklim tropis dan subtropis. Penyakit tersebut menyebar melalui gigitan nyamuk Anopheles sp. betina yang membawa parasit plasmodium. ${ }^{1-3}$ World Health Organization (WHO) melalui World Malaria Report (2018) menunjukkan terdapat 219 juta kasus malaria di dunia sepanjang tahun 2017. Asia Tenggara menduduki posisi tertinggi kedua di dunia dengan estimasi jumlah kasus malaria 5\% dari total kasus malaria dunia. ${ }^{4} \mathrm{Di}$ Indonesia, Riset Kesehatan Dasar (Riskesdas) 2018 mengungkapkan angka prevalensi malaria dihitung berdasarkan hasil pemeriksaan Rapid Diagnostic Test (RDT) adalah $0,6 \%{ }^{5}$

Sebagian besar data yang dikumpulkan menunjukkan terdapat penurunan kasus malaria sejak diberlakukan Global Technical Strategy (GTS) dan Sustainable Development Goals (SDGs) oleh WHO pada tahun 2016. Akan tetapi, pencapaian tersebut masih terlampau jauh dari target GTS dan SDGs. Hambatan utama yang dihadapi dunia dalam rangka Global Malaria Control(GMC) adalah penyebarankasus resistensi parasit terhadap obat-obatan malaria yang ada. ${ }^{4,6}$ Artemisinin-based combination therapies (ACTs) merupakan salah satu jenis pengobatan malaria yang efektif hingga mampu mencapai penurunan angka kasus malaria. Namun, saat ini telah ditemukan kasus resistensi parasit malaria terhadap artemisinin. Kasus resistensi artemisinin ataupun ACTs serta keterbatasan obat alternatif yang efektif menuntun peneliti dalam berinovasi untuk menemukan dan mengembangkan bahan baku obat baru antimalaria. ${ }^{7}$

Mayoritas penelitian pengembangan bahan baku obat memilih tanaman sebagai salah satu alternatif bahan mentahnya. Pemilihan jenis tanaman untuk pengembangan bahan baku obat dapat didasarkan melalui metode acak ataupun empiris. Salah satu metode empiris adalah eksplorasi keanekaragaman tanaman yang telah umum digunakan untuk pengobatan penyakit tertentu atau dikenal dengan riset etnomedisinal, etnobotani serta etnofarmakologi. ${ }^{8,9}$ Kaur $^{1}$ mengungkapkan sekurang-kurangnya terdapat 1.200 spesies tumbuhan yang memiliki bukti empiris ataupun ilmiah berpotensi sebagai antimalaria. Banyaknya spesies tumbuhan obat sebagai antimalaria menunjukkan bahwa pengembangan obat baru malaria perlu dilakukan secara berkelanjutan, baik sebagai obat baru ataupun kombinasi. Hal ini dikarenakan malaria 
memerlukan penanganan yang sangat kompleks, salah satunya karena kasus resistensi parasit terhadap obat yang semakin melebar setiap waktu. Disamping itu, terjadinya resistensi nyamuk malaria terhadap insektisida juga termasuk kendala dalam eliminasi malaria. ${ }^{10}$

Artemisia annua, Andrographis paniculate, Alstonia scholaris, Carica papaya, Cassia siamea dan sebagainya adalah beberapa spesies tumbuhan yang terbukti secara empiris hingga ilmiah berpotensi sebagai antimalaria. ${ }^{1,11,12}$ Beberapa kendala yang dihadapi pada pengembangan obat berbasis tumbuhan tersebut diantaranya resistensi parasit malaria terhadap senyawa aktifnya, ketersediaan jenis tumbuhan obat sebagai bahan baku yang terbatas, dan kompleksitas tahapan isolasi senyawa aktif spesifik antimalaria.,13,14 Sehingga, inovasi perlu dilakukan secara terus menerus untuk menemukan senyawa antimalaria berbasis tumbuhan yang paling efektif dan efisien.

Nauclea orientalis (L.) L atau gempol merupakan salah satu jenis tumbuhan yang digunakan dalam pengobatan tradisional malaria di beberapa etnis di Indonesia, diantaranya Bungku (Sulawesi Tengah), Buru dan Rana (Maluku), serta Marind (Papua). ${ }^{15-17}$ Berdasarkan data empiris Riset Tumbuhan Obat dan Jamu (Ristoja), batang $N$. orientalis (L.) L digunakan dalam pengobatan tradisional malaria. Penelitian lanjutan Ristoja tahun 2014 menunjukkan bahwa ekstrak air batang $N$. orientalis (L.) L memiliki aktivitas penghambatan polimerisasi hem dengan $\mathrm{IC}_{50} 13,86 \mu \mathrm{g} / \mathrm{mL} .^{18}$ Ekstrak kloroform batang gempol memiliki aktivitas antiplasmodium secara in vitro dengan nilai $\mathrm{IC}_{50}<5 \mu \mathrm{g} / \mathrm{mL}$. Hasil ekstrak tersebut dilanjutkan dengan bioassay guided fractionation yang diperoleh delapan fraksi. Nilai $\mathrm{IC}_{50}$ dari fraksi paling aktif sebesar $4,6 \mu \mathrm{g} / \mathrm{mL}$. Senyawa antimalaria yang berhasil diisolasi dari bagian batang, antara lain senyawa yang termasuk dalam golongan tetrahydro- $\beta$ carboline monoterpene alkaloid glucosides, naucleaorine, dan strictosidine lactam. Uji sitotoksisitas batang $N$. orientalis (L.) L pada cell line kanker epidermoid oral $\mathrm{KB}$ manusia diperoleh hasil bahwa sampel tersebut tidak bersifat toksik hingga konsentrasi $37 \mu \mathrm{M} .{ }^{19}$ Beberapa hasil penelitian tersebut memberikan bukti ilmiah terkait potensi bioaktif antimalaria batang $N$. orientalis (L.) L.

Substitusi bagian tumbuhan untuk obat merupakan salah satu upaya menjaga keberlangsungan hidup suatu spesies tumbuhan obat. Hal tersebut diperlukan karena kondisi saat ini menunjukkan bahwa 90\% tumbuhan yang digunakan sebagai obat dikoleksi secara liar langsung dari alam. Sebagian besar spesies tumbuhan obat di dunia mengalami kesalahan metode pemanenan yang berpotensi merusak hingga mengancam eksitensinya. Pemanfaatan batang, kulit batang, akar, dan tumbuhan utuh sebagai obat berpotensi menimbulkan kerusakan daripada menggunakan daun, bunga, buah, ataupun tunas. ${ }^{20,21}$

Berdasarkan data Ristoja, Etnis Moraid di Papua Barat menggunakan daun $N$. orientalis. (L) L untuk pengobatan malaria. Disamping itu, secara empiris daun $N$. orientalis (L.) L dalam Ristoja juga digunakan untuk mengobati sakit pencernaan, cedera tulang, perawatan pasca melahirkan, kencing manis dan gangguan pertumbuhan anak. ${ }^{15-17}$ Chadarat et al dalam Raghavamma dan Rao berhasil mengisolasi senyawa indole alkaloid glikosida dan angustinetype alkaloid dari ekstrak amonia daun. Senyawa tersebut diketahui memiliki aktivitas antiproliferasi pada sel kanker payudara MCF7 dan sel line leukimia. Hasil penelitian lain mengungkapkan aktivitas antianthelmintik dari ekstrak kloroform, aseton, etanol, dan air daun $N$. orientalis (L.) L. ${ }^{22}$ Potensi antimalaria daun tersebut belum banyak diteliti. Oleh karena itu, penelitian bertujuan untuk mengeksplorasi potensi antimalaria daun $N$. orientalis (L.) L sebagai alternatif bahan baku obat pengganti batang. 


\section{METODE}

Sampel $N$. orientalis (L.) L diperoleh dari Desa Karangwono, Kabupaten Pati, Jawa Tengah. Penyiapan sampel meliputi determinasi, sortasi dan pembuatan simplisia dilakukan di Balai Besar Tanaman Obat dan Obat Tradisional (B2P2TOOT), Tawangmangu. Gambar 1 merupakan tumbuhan $N$. orientalis (L.) L. yang digunakan sebagai sampel pada penelitian ini.

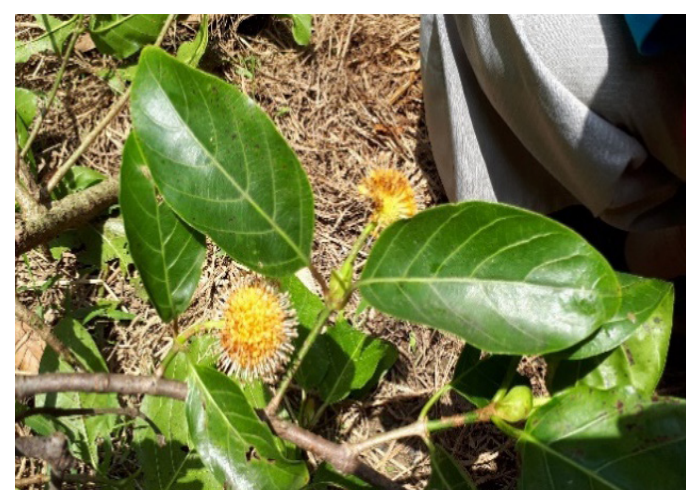

Gambar 1. Nauclea orientalis (L.) L

Proses ekstraksi dilakukan menggunakan metode standar penyiapan sediaan galenika dengan modifikasi. ${ }^{23}$ Daun $N$. orientalis (L.) L diekstrak dengan metode remaserasi, dimana sebanyak $1 \mathrm{~kg}$ simplisia yang dikeringkan dalam oven suhu $\pm 40^{\circ} \mathrm{C}$, diserbuk dan diayak pada saringan mesh 40 . Serbuk direndam dalam etanol $96 \%$ dengan perbandingan 1:5 (b/v) selama 3 x 24 jam. Hasil rendaman disaring dengan kertas saring, kemudian filtrat yang dihasilkan dilakukan pemekatan menggunakan rotary evaporator vaccum dan dikeringkan dalam oven $\mathrm{suhu} \pm 40^{\circ} \mathrm{C}$. Ampas sisa perendaman atau residu direndam kembali dalam etanol $96 \%$ dengan perbandingan dan waktu perendaman yang sama seperti proses maserasi pertama. Ekstrak kering dari hasil setiap tahapan maserasi digabung, berikutnya ditimbang dan ditentukan persentase nilai rendemennya. Persentase nilai rendemen ditentukan dengan rumus perhitungan sebagai berikut:

Rendemen $(\%)=\frac{\text { W ekstrak atau fraksi }(\mathrm{g})}{\mathrm{W} \text { sampel }(\mathrm{g})} \times 100 \%$
Ekstrak etanol yang dihasilkan dilanjutkan dengan proses fraksinasi bertingkat dari pelarut non-polar hingga polar. Metode fraksinasi ini merujuk pada publikasi tentang isolasi dan karakterisasi senyawa aktif dengan modifikasi. Jenis pelarut yang digunakan berturut-turut adalah heksana, etil asetat, dan metanol. Fraksinasi dilakukan dengan metode partisi cair-cair, pertama menyiapkan sampel ekstrak sebanyak 10 gram. Ekstrak etanol tersebut dilarutkan dalam akuades steril. Partisi pertama dilakukan menggunakan pelarut heksana pengulangan beberapa kali hingga warna larutan tidak terlalu pekat/memudar. Filtrat yang dihasilkan dipekatkan dengan rotary evaporator vaccum, dikeringkan dalam oven suhu $\pm 40^{\circ} \mathrm{C}$ dan ditentukan persentase nilai rendemennya. Residu hasil partisi cair-cair dikeringkan dalam oven suhu $\pm 40^{\circ} \mathrm{C}$ hingga diperoleh bobot konstan untuk menghilangkan pelarut sebelumnya. Hasil residu kering dilakukan partisi kembali dengan metode yang sama seperti sebelumnya, berturutturut menggunakan pelarut etil asetat dan metanol.

Pengujian aktivitas antimalaria dilakukan di Laboratorium Malaria, Institute of Tropical Disease (ITD) dengan standar Bio Safety Level (BSL) 3, Universitas Airlangga, Surabaya. Pengujian antimalaria menggunakan parasit Plasmodium falciparum (P. falciparum) strain 3D7 yang dilakukan secara in vitro sesuai metode dasar Trager and Jensen dengan pewarnaan Giemsa. ${ }^{24}$ Kontrol positif yang digunakan adalah artemisinin 98\% (Sigma Aldrich 361593) dengan seri konsentrasi 0,$01 ; 0,001 ; 0,0001 ; 0,00001$; dan $0,000001 \mu \mathrm{g} / \mathrm{mL}$. Larutan DMSO 2\% (v/v) digunakan sebagai kontrol negatif dalam setiap pengujian. Seri konsentrasi bahan uji baik ekstrak ataupun fraksi yang digunakan pada pengujian, yaitu $100 ; 10 ; 1 ; 0,1$ dan $0,01 \mu \mathrm{g} / \mathrm{mL}$. Pemilihan seri konsentrasi untuk artemisinin dan sampel didasarkan pada penelitian sebelumnya dengan modifikasi. $^{24,25}$ Penyiapan seri konsentrasi dilakukan dengan melarutkan $10 \mathrm{mg}$ kontrol positif dan bahan uji dengan dimetil sulfoksida (DMSO) $100 \mu \mathrm{L}, \quad$ kemudian diencerkan 
menggunakan media lengkap yang terbuat dari larutan HEPES dan hipoksantin, larutan Roswell Park Memorial Institute (RPMI) 1640, larutan $\mathrm{NaHCO}_{3}$, dan larutan gentamisin serta telah melalui proses sterilisasi. Pada saat pengujian, masing-masing bahan uji dimasukkan ke dalam 24 microwell plate disposable dan ditambahkan suspensi biakan parasit $1 \%$ dan hematokrit $5 \%$. Kultur tersebut dilakukan inkubasi selama 48 jam pada suhu $37^{\circ} \mathrm{C}$. Hasil kultur dipanen dan dibuat sediaan hapusan darah tipis serta dilakukan pewarnaan menggunakan giemsa $20 \%$. Hapusan darah tipis yang telah kering, diperiksa di bawah mikroskop dengan perbesaran 10x100. Selanjutnya, ditentukan beberapa parameter hasil pengujian seperti persentase pertumbuhan dan persentase penghambatan. Rumus perhitungan untuk menentukan parameter persentase pertumbuhan, yaitu:

\section{$\%$ pertumbuhan $=\%$ parasitemia-D0}

D0 adalah persentase pertumbuhan pada jam ke 0 . Sedangkan rumus perhitungan persentase penghambatan adalah:

$$
\% \text { penghambatan }=100 \%-(\mathrm{Xu} / \mathrm{Xk}) \times 100 \%
$$

$\mathrm{Xu}$ merupakan persentase pertumbuhan pada larutan uji dan $\mathrm{Xk}$ adalah persentase pertumbuhan pada kontrol negatif.

Penapisan senyawa fitokimia dilakukan dengan Kromatografi Lapis Tipis (KLT) berdasarkan prosedur standar farmakognosi dengan modifikasi. ${ }^{26}$ Tujuan penapisan senyawa fitokimia adalah untuk mengetahui jenis-jenis senyawa metabolit sekunder yang terkandung dalam masing-masing bahan uji. Tahapan kerja penapisan senyawa fitokimia diawali dengan penimbangan sejumlah $10 \mathrm{mg}$, dilarutkan dalam kloroform: metanol (1:1), dan dihomogenkan. Filtrat larutan sampel ditotolkan dengan alat Thin Layer Chromatography (TLC) densitometer pada plat silika $\mathrm{F}_{254}$ (Milipore) sebanyak $2 \mu \mathrm{L}$. Plat dengan totolan sampel dilakukan elusi dengan eluen campuran berupa heksana: etil asetat: metanol (4:3:1) hingga tanda batas $1 \mathrm{~cm}$ dari tepi atas. Berikutnya, hasil elusi dilakukan penambahan reagen penampak bercak, seperti dragendroff, sitroborat dan Liebermannbourchad. Reagen dragendorff berfungsi untuk mendeteksi kandungan senyawa alkaloid, sitroborat untuk flavonoid, dan Liebermannburchad untuk terpenoid. Hasil tersebut dilanjutkan dengan pengamatan di bawah sinar UV-Visible pada alat TLC visualizer dipanjang gelombang yang sesuai $(254 / 365 \mathrm{~nm})$.

Parameter aktivitas antimalaria dihitung dengan analisis regresi linier menggunakan probit log dengan software statistical package for the social sciences (SPPS) IBM 21 untuk diperoleh hasil akhir berupa nilai $\mathrm{IC}_{50}$ atau konsentrasi bahan uji yang mampu menghambat pertumbuhan plasmodium sebesar 50\%. Nilai $\mathrm{IC}_{50}$ yang diperoleh dilakukan uji statistika dengan analisis One Way Analysis of Variance (ANOVA) dilanjutkan dengan post hoc Least Significant Difference (LSD) $(\alpha=0,05)$ untuk melihat perbedaan nilai rata-rata.

\section{HASIL}

\section{Rendemen Ekstrak}

Persentase rendemen tertinggi dihasilkan saat dilakukan partisi cair-cair menggunakan pelarut heksana, yaitu sebesar $20 \%$. Nilai rendemen masing-masing ekstrak dicantumkan pada Gambar 2.

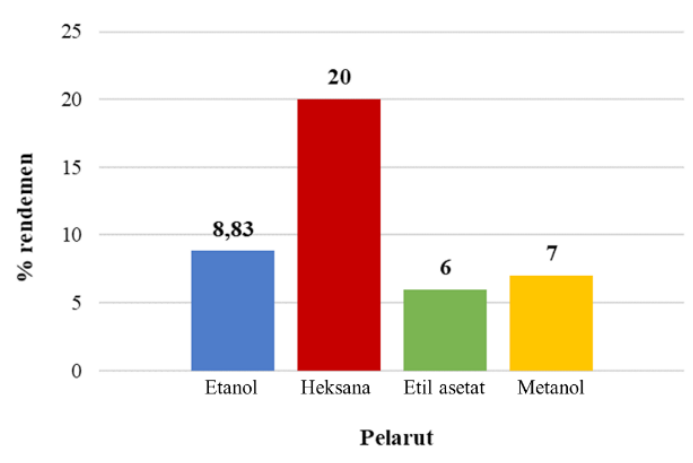
Gambar 2. Persentase Rendemen
Masing-Masing Sampel 


\section{Aktivitas Antimalaria Secara In Vitro}

Pemberian sampel berupa ekstrak atau fraksi daun $N$. orientalis (L.) L, masing-masing dapat menurunkan persentase pertumbuhan parasit $P$. falciparum 3D7. Grafik penurunan persentase pertumbuhan parasit ditunjukkan pada Gambar 3.

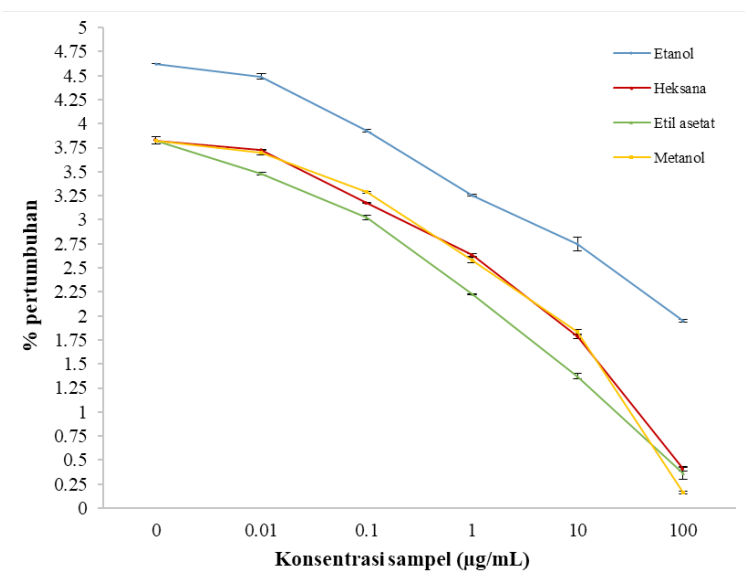

Gambar 3. Hubungan Konsentrasi Dosis Masingmasing Sampel dengan \% Pertumbuhan $P$. falciparum 3D7

Semakin tinggi konsentrasi dosis sampel menunjukkan semakin rendah nilai persentase pertumbuhan parasit malaria. Kondisi tersebut berlaku untuk masing-masing sampel, baik ekstrak ataupun fraksi.

Masing-masing ekstrak ataupun fraksi diketahui juga mampu menghambat pertumbuhan P. falciparum 3D7. Hal ini ditunjukkan oleh persentase penghambatan untuk masing-masing sampel pada seri konsentrasi (Gambar 4).

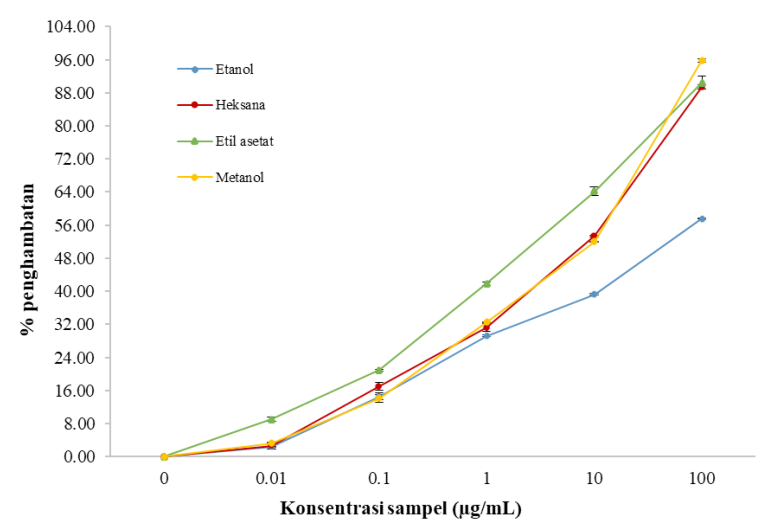

Gambar 4. Hubungan Konsentrasi Dosis Masingmasing Sampel dengan \% Penghambatan $P$. falciparum 3D7
Kecenderungan persentase penghambatan akan semakin meningkat bersama dengan peningkatan konsentrasi sampel uji, baik ekstrak ataupun fraksi.

Hasil penetapan nilai $\mathrm{IC}_{50}$ aktivitas antiplasmodium secara in vitro menunjukkan secara umum ekstrak daun $N$. orientalis (L.) L berpotensi sebagai antimalaria. Fraksi heksana, etil asetat, dan metanol, berturut-turut dengan nilai $\mathrm{IC}_{50} 2,79,4,49$ dan $4,18 \mu \mathrm{g} / \mathrm{mL}$ termasuk dalam kategori highly active (Tabel 1).

Tabel 1. Nilai IC $_{50}$ Ekstrak dan Fraksi Daun $N$. orientalis (L.) $\mathbf{L}$

\begin{tabular}{ccc}
\hline Sampel & $\mathbf{I C}_{\mathbf{5 0}}(\mu \mathrm{g} / \mathrm{mL})$ & Kategori \\
\hline Klorokuin fosfat* & 0,035 & - \\
Artemisinin & $0,000332 \pm$ & - \\
& 0,00000 & \\
Etanol & $30,80 \pm 0,52$ & moderate activity \\
Heksana & $2,79 \pm 0,19$ & highly active \\
Etil asetat & $4,49 \pm 0,15$ & promisingly active \\
Metanol & $4,18 \pm 0,32$ & highly active \\
\hline
\end{tabular}

*Penelitian Sara et al (2011)

\section{Penapisan Senyawa Fitokimia}

Kromatogram profil senyawa fitokimia masing-masing sampel uji, baik ekstrak ataupun fraksi ditunjukkan pada Gambar 5. Pada kromatogram tersebut menunjukkan adanya perbedaan profil kandungan metabolit sekunder atau senyawa fitokimia dalam masing-masing sampel uji.

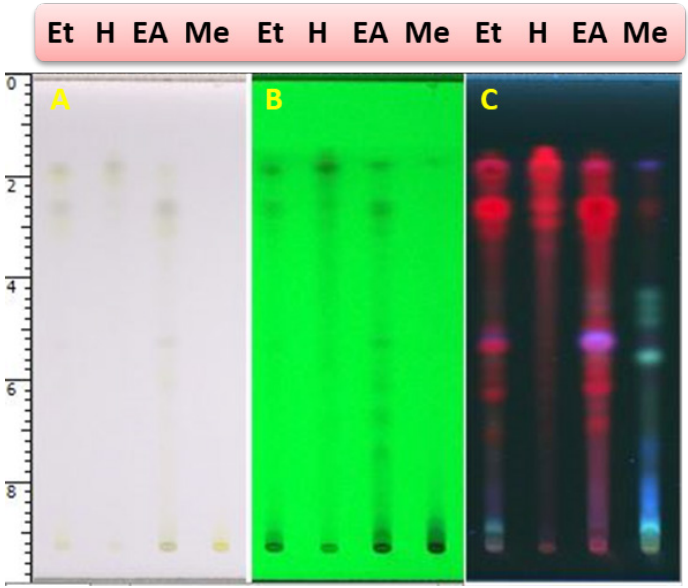

Keterangan

\begin{tabular}{|c|c|}
\hline it : etanol & EA \\
\hline heksana & $\mathrm{Me}$ \\
\hline
\end{tabular}




\section{Gambar 5. Profil Fitokimia Ekstrak dan Fraksi Daun $N$. orientalis (L.) L pada Fase Diam Plat Silika dan Fase Gerak Heksana: Etil Asetat: Metanol (4:3:1) (Cahaya Tampak (A), 254 nm (B), $366 \mathrm{~nm}(\mathrm{C}))$}

Hasil penapisan fitokimia pada kromatogram tersebut menunjukkan ekstrak atau fraksi memiliki kandungan beragam senyawa seperti yang dicantumkan pada Tabel 2 .

Tabel 2. Hasil Penapisan Senyawa Fitokimia Ekstrak dan Fraksi Daun $N$. orientalis (L.) L

\begin{tabular}{ll}
\hline \multicolumn{1}{c}{ Sampel } & \multicolumn{1}{c}{ Kandungan senyawa } \\
\hline Etanol & steroid, flavonoid, terpenoid \\
Heksana & alkaloid, steroid, flavonoid, terpenoid \\
Etil asetat & alkaloid, steroid, flavonoid, terpenoid \\
Metanol & steroid, flavonoid \\
\hline
\end{tabular}

\section{PEMBAHASAN}

Persentase rendemen daun $N$. orientalis (L.) L secara berturut-turut adalah heksana > etanol $>$ metanol $>$ etil asetat. Truong et al. ${ }^{27}$ mengungkapkan bahwa kuantitas rendemen tergantung pada sifat kelarutan atau polaritas komponen bioaktif yang terkandung dalam bahan alam tersebut. Pada penelitian ini, rendemen tertinggi diperoleh dari hasil partisi dengan pelarut heksana (pro analysis), yaitu sebanyak $20 \%$. Hal tersebut menunjukkan bahwa daun $N$. orientalis (L.) L memiliki kandungan senyawa berindeks polaritas yang sesuai dengan pelarut heksana, yaitu sebesar nol. Komponen yang dapat terlarut dalam heksana umumnya berupa senyawa lipofilik, seperti alkana, lilin, pigmen, sterol, sebagian terpenoid dan alkaloid. ${ }^{28}$ Tingginya nilai rendemen tersebut menunjukkan juga bahwa pelarut heksana merupakan pelarut yang paling optimal digunakan untuk mengekstraksi daun $N$. orientalis (L.) L dibandingkan pelarut lain.

Aktivitas antimalaria ekstrak ataupun fraksi terbagi menjadi beberapa kategori sebagai berikut: highly active $\left(\mathrm{IC}_{50}<5 \mu \mathrm{g} /\right.$ $\mathrm{mL}$ ), promisingly active $\left(\mathrm{IC}_{50} 5,1-10 \mu \mathrm{g} / \mathrm{mL}\right)$, good activity $\left(\mathrm{IC}_{50} 10,1-20 \mu \mathrm{g} / \mathrm{mL}\right)$, moderate belum mampu mencapai keefektifan senyawa artemisinin. Sehingga kedua jenis fraksi tersebut berpotensi untuk dikembangkan lebih lanjut sebagai alternatif senyawa antimalaria.

Penelitian sebelumnya pada batang $N$. orientalis (L.) L diketahui ekstrak kloroformnya memiliki aktivitas antimalaria dengan $\mathrm{IC}_{50} 3$ dan 6 $\mu \mathrm{g} / \mathrm{mL}$ berturut-turut diujikan pada $P$. falciparum clone D6 dan W2. Ekstrak kloroform tersebut dilakukan fraksinasi hingga berhasil diisolasi delapan senyawa dengan nilai $\mathrm{IC}_{50}$ terkecil adalah 4,6 $\mu \mathrm{M}$ pada isolat ke delapan. ${ }^{19}$ Fakta tersebut menunjukkan bahwa batang ataupun daun $N$. orientalis (L.) L, sampel ekstrak ataupun fraksinya memiliki aktivitas antiplasmodium yang termasuk kategori highly active $\left(\mathrm{IC}_{50}<5\right.$ $\mu \mathrm{g} / \mathrm{mL}$ ). Persamaan tersebut menunjukkan bahwa daun dapat mensubtitusi batang $N$. orientalis (L.) $\mathrm{L}$ dalam pengembangan alternatif bahan obat antimalaria.

Selain batang $N$. orientalis (L.) L, batang $N$. officinalis dan $N$. pobeguinii juga diketahui memiliki aktivitas antiplasmodium dengan kategori poor $\left(\mathrm{IC}_{50} 70,1\right.$ hingga $>100 \mu \mathrm{g} / \mathrm{mL}$ ) dan moderate $\left(\mathrm{IC}_{50}>20,1-40 \mu \mathrm{g} / \mathrm{mL}\right)$ activity. ${ }^{32,33}$ Berdasarkan publikasi tersebut menunjukkan bahwa daun $N$. orientalis (L.) L lebih efektif dan berpotensi untuk dikembangkan sebagai alternatif bahan baku obat antimalaria baru, karena memiliki aktivitas antiplasmodium dalam kategori highly active $\left(\mathrm{IC}_{50}<5 \mu \mathrm{g} / \mathrm{mL}\right)$. Jenis senyawa aktif antiplasmodium pada batang $N$. orientalis (L.) L diketahui sebagai asam oleanolik yang termasuk dalam golongan triterpenoid. ${ }^{19}$ Sampel fraksi aktif pada penelitian ini perlu dilakukan evaluasi lebih mendalam agar dapat diketahui jenis senyawa aktif spesifik yang bertanggungjawab sebagai antiplasmodium dalam daun $N$. orientalis (L.) L.

Hasil uji statistika one way ANOVA dan post hoc LSD pada masing-masing nilai $\mathrm{IC}_{50}$ menunjukkan bahwa nilai $\mathrm{IC}_{50}$ untuk kontrol positif, ekstrak etanol, dan fraksi heksana berbeda signifikan $(p<0,05)$. Namun, nilai $\mathrm{IC}_{50}$ antara fraksi etil asetat dan metanol tidak berbeda signifikan $(p>0,05)$ dan berada dalam kelompok yang sama. Hal ini menunjukkan bahwa jenis 
sampel berpengaruh pada aktivitasnya. Sampel pada penelitian ini berbeda jenis media pelarut ekstrak yang juga dapat mempengaruhi senyawa aktif yang dapat terlarut.

Tabel 2 menunjukkan fraksi heksana daun $N$. orientalis (L.) L diketahui memiliki kandungan senyawa alkaloid, steroid, flavonoid, dan terpenoid. Di lain pihak, senyawa steroid dan flavonoid dapat dideteksi pada fraksi metanol. Beberapa penelitian terdahulu menunjukkan bahwa kandungan utama dalam ekstrak amonia daun $N$. orientalis (L.) L adalah senyawa indole alkaloid, akan tetapi hingga kini belum ada informasi terkait aktivitasnya sebagai antimalaria. ${ }^{34}$ Bagian batang dan kulit batang diketahui juga sebagian besar memiliki kandungan senyawa alkaloid, alkaloid glikosida, dan indole alkaloid. ${ }^{35,36} \mathrm{Hal}$ ini sesuai dengan hasil skrining fitokimia pada penelitian ini, yaitu terdapat kandungan alkaloid dalam ekstrak ataupun fraksinya. Kandungan senyawa metabolit sekunder diduga memiliki peran aktif dalam menghambat pertumbuhan plasmodium. Hal ini sesuai dengan hasil beberapa penelitian yang mengungkapkan bahwa senyawa-senyawa metabolit sekunder seperti alkaloid, terpenoid, flavonoid, kumarin, fenolik, poliasetilat, xanthone, kuinon, steroid dan lignan diketahui berpotensi untuk dikembangkan sebagai antimalaria. ${ }^{37,38}$

Alkaloid merupakan senyawa metabolit sekunder dengan struktur dasar nitrogen yang dapat diproduksi dari beragam prekursor. Senyawa alkaloid termasuk golongan metabolit sekunder utama yang diketahui berpotensi sebagai antimalaria. ${ }^{39,40}$ Saxena et $a l^{41}$ mengungkapkan bahwa berdasarkan publikasi terdahulu terdapat lebih dari 100 jenis senyawa alkaloid dengan aktivitas antimalaria. Beberapa jenis alkaloid dengan aktivitas antimalaria tersebut dikelompokkan berdasarkan strukturnya, diantaranya bisbenzylisoquinolines, aporphine-benzylisoquinoline, morphinan, naphtylisoquinolines, indoquinoline, monodan bis-indole alkaloid, indolomonoterpenoid, indole alkaloid, benzofenantridine, acridone, tetrahydroquinoline, cryptolepinesdan amida..$^{38,40}$
Sebagian besar mekanisme kerja senyawa alkaloid adalah dengan menghambat pertumbuhan parasit plasmodium melalui pembentukan ikatan dengan DNA ataupun penghambatan sintesis proteinnya. ${ }^{42}$

Beberapa jenis senyawa steroid yang diketahui memiliki aktivitas antimalaria, diantaranya ergosterol-5, 8-endoperoxide, steroidal saponin (diosgenone) seperti vernonioside, sapogenin, arylmethylamino steroid, dan 16 alpha-acetoxy-26-hydroxycholest4-ene-3, 22-dione ( $\mathrm{SN}-1$ ) steroid. ${ }^{43-46}$ Kelebihan dari golongan steroid adalah sifat hidrofobiknya yang sesuai dengan permeabilitas membran sehingga mampu memfasilitasi senyawa aktif masuk ke dalam sel. Salah satu mekanisme kerja steroid sebagai antimalaria, yaitu menghambat pertumbuhan parasit melalui penghambatan pembentukan hemozoin. ${ }^{46}$

Flavonoid merupakan salah satu senyawa dengan keragaman struktur dan potensi bioaktif yang sangat tinggi, salah satunya sebagai antimalaria. Senyawa spesifik yang tergolong dalam flavonoid dan diketahui bersifat bioaktif sebagai antimalaria, antara lain lupinifolin, citflavanone, erythrienegalone, lonchocarpol A, licochalcone A, liquiritigenin, 8-prenyladaidzein, diprenyl flavone, acacetin, calycosin, genistein, cathechin, luteolin, dan masih banyak lainnya. ${ }^{47-50}$ Golongan senyawa flavonoid memiliki kemampuan untuk menghambat pertumbuhan parasit melalui dua cara, yaitu menganggu transportasi nutrisi yang diperlukan oleh parasit dan melakukan penghambatan katabolisme hemoglobin serta detoksifikasi hem. ${ }^{50,51}$

Golongan terpenoid dengan aktivitas antimalaria dapat dikelompokan menjadi beberapa sub kelas, diantaranya iridoid, monoterpene terhalogenasi, tetranorditerpenes, diterpene ternitrogenasi, terpenoid benzoquinones, cleorodanes, labdanes, limonoid, bisnorterpenes, triterpene akrilik, cassane furanoditerpenes, abietane diterpenes, sesquiterpenes, beilshmiedic acid dan turunannya, serta triterpene pentasiklik. ${ }^{38,52}$ Struktur senyawa terpenoid dan turunannya memungkinkan untuk 
dapat memasuki membran eritrosit hingga ke dalam sel melalui lipid bilayer, kondisi tersebut mengakibatkan penghambatan pertumbuhan dan infasi parasit malaria. Selain itu, golongan terpenoid juga mampu mengganggu pertumbuhan parasit dengan menghambat sintesis protein dalam sel parasit. ${ }^{53,54}$

Hasil kajian terkait bioaktivitas golongan senyawa alkaloid, steroid, flavonoid, dan terpenoid sebagai antimalaria tersebut menunjukkan bahwa ekstrak atau fraksi daun N. orientalis (L.) L memiliki potensi untuk dikembangkan lebih lanjut. Komponen bioaktif yang terdapat pada fraksi heksana dan metanol daun $N$. orientalis (L.) L dapat dilakukan pemisahan dan pemurnian lebih lanjut agar dapat meningkatkan efektivitasnya terhadap parasit malaria. Daun N. orientalis (L.) $\mathrm{L}$ diharapkan dapat menjadi alternatif sumber bahan obat malaria.

\section{KESIMPULAN}

Fraksi heksana daun $N$. orientalis (L.) L memiliki potensi sebagai antiplasmodium yang paling efektif dibandingkan sampel lain. Hal ini didukung oleh nilai rendemennya yang tertinggi dan aktivitas antiplasmodium yang paling efektif, yaitu dengan $\mathrm{IC}_{50} 2,79 \mu \mathrm{g} / \mathrm{mL}$ yang menempatkannya pada kategori highly active bersama dengan fraksi etil asetat dan metanol. Aktivitas daun $N$. orientalis (L.) L sebagai antiplasmodium mampu menggantikan bagian batang sehingga lebih efisien untuk bahan baku obat. Mayoritas senyawa yang terkandung dalam fraksi heksana adalah alkaloid, steroid, flavonoid, dan terpenoid.

\section{SARAN}

Penelitian lebih mendalam terkait pemisahan dan pemurnian terhadap fraksi aktif daun $N$. orientalis (L.) L agar mampu meningkatkan keefektifan potensinya sebagai antimalaria. Disamping itu, pengujian toksisitas daun $N$. orientalis (L.) L juga perlu dilakukan untuk menjamin keamanan penggunaan spesies tersebut.

\section{UCAPAN TERIMA KASIH}

Terimakasih kepada Rohmat Mujahid, M.Sc., Apt (B2P2TOOT Tawangmangu) untuk bimbingannya selama pelaksanaan penelitian. Hilkatul Ilmi, M.Si (TDC Universitas Airlangga) atas bantuannya pada pengujian in vitro sampel, Kumiati, S.Si, Zulaikah Tri Hastuti, A.Md, dan tim penelitian lanjutan Ristoja antimalaria B2P2TOOT Tawangmangu yang membantu kelancaran pelaksanaan kegiatan penelitian ini.

\section{DAFTAR PUSTAKA}

1. Kaur R, Kaur H. Plant Derived Antimalarial Agents. J Med Plants Stud. 2017;5(1):346-63.

2. WHO. World Malaria Report 2016. World Health Organization; 2017. Available from: http://www. who.int/malaria/publications/world-malariareport-2016/en/

3. Okello D, Kang Y. Review Article: Exploring Antimalarial Herbal Plants across Communities in Uganda Based on Electronic Data. EvidenceBased Complement Altern Med. 2019;1-27.

4. WHO. World Malaria Report 2018. Luxembourg: WHO; 2018.

5. Badan Litbang Kesehatan. Laporan Nasional Riskesdas 2018. Jakarta: Badan Litbang Kesehatan; 2018.

6. Foko LPK, Meva FE, Moukoko CEE, Ntoumba AA, Njila MLN, Kedi PBE, et al. A Systematic Review on Anti-Malarial Drug Discovery and Antiplasmodial Potential of Green Synthesis Mediated Metal Nanoparticles: Overview, Challenges And Future Perspectives. Malar J. 2019;18:337. Available from: https://doi. org/10.1186/s12936-019-2974-9

7. Ouji M, Augereau JM, Paloque L, BenoitVical F. Plasmodium Falciparum Resistance to Artemisinin-Based Combination Therapies: A sword of Damocles in the Path Toward Malaria Elimination. Parasite. 2018;25(24):1-12.

8. Ezenyi IC, Salawu OA. Approaches, Challenges and Prospects of antimalarial Drug Discovery from Plant Sources. In: Current Topics in Malaria. INTECH Open Access Publisher; 2016. p. 187205. 
9. Pandey AK, Tripathi Y. Ethnobotany and Its Relevance in Contemporary Research. J Med Plants Stud. 2017;5(3):123-9.

10. Choubey V, Dubey P. Some Antimalarial Plants of Tribal Regions of M. P. J Environ Sci Toxicol Food Technol. 2015;1(5):42-5.

11. Widyawaruyanti A, Asrory M, Ekasari W, Setiawan D. In Vivo Antimalarial Activity of Andrographis Paniculata Tablets. Procedia Chem. 2014;13:101-4. Available from: http://dx.doi. org/10.1016/j.proche.2014.12.012

12. Raharjo A, Ekasari W, Hafid AF. Uji Aktivitas Antimalaria Ekstrak Air Daun Johar (Cassia siamea Lamk) terhadap Plasmodium berghei secara In Vivo. J Farm dan Ilmu Kefarmasian Indones. 2014;1(1):6-9.

13. Widiyastuti Y, Subositi D, Ekasari W. Pengembangan Johar (Senna siamea) sebagai Obat Baru Malaria. 2017. Available from: http:// repository.litbang.kemkes.go.id/3060/

14. Anindita V, Mutiara H, Mutiara UG. Mutasi Gen Kelch 13 dan Resistensi Plasmodium falciparum terhadap Obat Antimalaria Golongan Artemisinin. Medula. 2017;7(5):149-53.

15. Wahyono $\mathrm{S}$ et al. Laporan Nasional : Ekplorasi Pengetahuan Lokal Etnomedisin dan Tumbuhan Obat di Indonesia Berbasis Komunitas 2012. Jakarta: Badan Litbangkes; 2012.

16. Wahyono S et al. Laporan Nasional : Ekplorasi Pengetahuan Lokal Etnomedisin dan Tumbuhan Obat di Indonesia Berbasis Komunitas 2015. Jakarta : Badan Litbangkes; 2015.

17. Wahyono S, Jokopriyambodo W, Rahmawati N, Maruzy A, Widowati L, Subositi D, et al. Laporan Nasional : Ekplorasi Pengetahuan Lokal Etnomedisin dan Tumbuhan Obat di Indonesia Berbasis Komunitas 2017. Jakarta: Badan Litbangkes; 2017.

18. Supriyati, Nita D. Analisis Lanjut Tahap I: Skrining Aktifitas Ramuan RISTOJA untuk Malaria, Kanker dan TBC, Analisis Chemical Profiling dan DNA Fingerprinting Tumbuhan Obat Terpilih. Tawangmangu; 2015.
19. He Z, Ma C, Zhang H, Teng G, Tamez P. Antimalarial Constituents from Nauclea orientalis (L.) L. Chem Biodivers. 2005;2:137886.

20. Shinde A, Gahunge P, Rath SK. Conservation and Sustainability of Ashwagandha: a Medicinal Plant. J Biol Sci Opin. 2015;3(2):94-9.

21. Chen SL, Yu H, Luo HM, Wu Q, Li CF, Steinmetz A. Conservation and Sustainable Use of Medicinal Plants: Problems, Progress, and Prospects. Chin Med. 2016;11(37):1-10.

22. Raghavamma STV, Rao NR. In Vitro Evaluation of Anthelmintic Activity of Nauclea Orientalis Leaves. Indian J Pharm Sci. 2010 Jul;72(4):5201.

23. Njila MIN, Mahdi E, Lembe DM, Nde Z, Nyonseu D. Review on Extraction and Isolation of Plant Secondary Metabolites. In 2017. Available from: https://doi.org/10.15242/IIE.C0517024

24. Hafid AF, Puliansari N, Lestari NS, Tumewu L, Rahman A, Widyawaruyanti A. Skrining Aktivitas Antimalaria Beberapa Tanaman Indonesia Hasil Eksplorasi Dari Hutan Raya Cangar, Batu-Malang, Jawa Timur. J Farm Dan Ilmu Kefarmasian Indones. 2017;3(1):7.

25. Badi'ah, R. Uji Aktivitas Fraksi Etil Asetat Daun Bunga Matahari (Helianthus annuus L.) sebagai antimalaria pada parasit Plasmodium falciparum strain 3D7. Universitas Islam Negeri Maulana Malik Ibrahim Malang; 2017.

26. Evans WC. Trease and Evans Pharmacognosy 16th edition. Saunders Elsevier; 2009. 604 p.

27. Truong DH, Nguyen DH, Ta NTA, Bui AV, Do TH, Nguyen HC. Evaluation of the Use of Different Solvents for Phytochemical Constituents, Antioxidants, and in Vitro Anti-Inflammatory Activities Of Severinia Buxifolia. J Food Qual. $2019 ; 2019$.

28. Yusnawan E. Prosiding Seminar Hasil Penelitian Tanaman Aneka Kacang dan Umbi. In: Prosiding Seminar Hasil Penelitian Tanaman Aneka Kacang dan Umbi. Balai Penelitian Tanaman Aneka Kacang dan Umbi; 2013. p. 239-405. 
29. Singh N, Kaushik NK, Mohanakrishnan D, Tiwari SK, Sahal D. Antiplasmodial Activity of Mmedicinal Plants from Chhotanagpur Plateau, Jharkhand, India. J Ethnopharmacol. 2015;165(July 2019):152-62. Available from: http://dx.doi.org/10.1016/j.jep.2015.02.038

30. Rasoanaivo P, Wright CW, Willcox ML, Gilbert B. Whole Plant Extracts Versus Single Compounds for the Treatment Of Malaria: Synergy And Positive Interactions. Malar J. 2011 Mar; 10(Suppl 1):S4. Available from: http://malariajournal. biomedcentral.com/articles/10.1186/1475-287510-S1-S4

31. Fidock DA, Rosenthal PJ, Croft SL, Brun R, Nwaka S, Einstein A. Antimalarial Drugg Discover: Efficacy Models for Compound Screening. Nat Rev. 2004;3(June):509-20.

32. Sun J, Lou H, Dai S, Xu H, Zhao F, Liu K. Indole Alkoloids from Nauclea Officinalis with weak Antimalarial Activity. Phytochemistry. 2008;69(6):1405-10.

33. Mesia K, Cimanga RK, Dhooghe L, Cos P, Apers $\mathrm{S}$, Totté J, et al. Antimalarial Activity and Toxicity Evaluation of a Quantified Nauclea Pobeguinii Extract. J Ethnopharmacol. 2010;131(1):10-6. Available from: http://dx.doi.org/10.1016/j. jep.2010.05.008

34. Erdelmeier CAJ, Regenass U, Rali T, Sticher O. Indole Alkaloids with in Vitro Antiproliferative Activity from the Ammoniacal Extract of Nauclea orientalis1. Planta. 1992;58:43-8.

35. He ZD, Qiao CF, Han Q Bin, Cheng CL, Xu HX, Jiang RW, et al. Authentication and Quantitative Analysis on the Chemical Profile of Cassia Bark (Cortex Cinnamomi) by High-Pressure Liquid Chromatography. J Agric Food Chem. 2005;53(7):2424-8.

36. Zhang Z, Elsohly HN, Jacob MR, Pasco DS, Walker LA, Clark AM. New Indole Alkaloids from the Bark of Nauclea orientalis. J Nat Prod. 2001;64(8):1001-5.
37. Ntie-Kang F, Onguéné PA, Lifongo LL, Ndom JC, Sippl W, Mbaze LMA. The Potential of Anti-Malarial Compounds Derived from African Medicinal Plants, Part II: a Pharmacological Evaluation of Non-Alkaloids and NonTerpenoids. Malar J. 2014;13(1):1-20.

38. Amoa Onguéné P, Ntie-Kang F, Lifongo LL, Ndom JC, Sippl W, Mbaze LMA. The Potential of Anti-malarial Compounds Derived from African Medicinal Plants, Part I: a Pharmacological Evaluation of Alkaloids and Terpenoids. Malar J. 2013;12(1):1-25.

39. Omar AW, Patimah I. Plant-derived Antimalarial Agents: from Crude Extracts To isolated Bioactive Compounds. Malaysian J Med Heal Sci. 2011;7(June):87-97.

40. Oliveira A, Dolabela M, Braga F, Jacome R, Varotti F, Povoa M. Plant-derived Antimalarial Agents: New Leads and Efficient Phythomedicines. Part I. alkaloids. Ann Brazilian Acad Sci. 2009;81(4):715-40. Available from: www.scielo. br/aabc

41. Saxena S, Pant N, Jain DC, Bhakuni RS. Antimalarial Agents From Plant Sources. Curr Sci. 2003;85(9):1314-29.

42. Brandão MGL, Krettli AU, Soares LSR, Nery CGC, Marinuzzi HC. Antimalarial Activity of Extracts and Fractions from Bidens pilosa and other Bidens species (Asteraceae) Correlated with the Presence of Acetylene and Flavonoid Compounds. J Ethnopharmacol. 1997;57(2):1318 .

43. Kuria KAM, Chepkwony H, Govaerts C, Roets E, Busson R, de Witte P, et al. The Antiplasmodial Activity of Isolates from Ajuga Remota. J Nat Prod. 2002;65(5):789-93.

44. Ohigashi H, Huffman MA, Izutsu D, Koshimizu K, Kawanaka M, Sugiyama H, et al. Toward the Chemical Ecology of Medicinal Plant Use in Chimpanzees: the Case of Vernonia amygdalina, a Plant Used by Wild Chimpanzees Possibly for Parasite-Related Diseases. J Chem Ecol. 1994;20(3):541-53. 
45. Pabón A, Deharo E, Blair S. Plasmodium falciparum: Solanum Nudum SN-1 Steroid Antiplasmodial Activity when Combined with Antimalarial Drugs. Exp Parasitol. 2011;127:2227.

46. Krieg R, Jortzik E, Goetz AA, Blandin S, Wittlin S, Elhabiri M, et al. Arylmethylamino Steroids as Antiparasitic Agents. Nat Commun. 2017;8.

47. Batista R, De Jesus Silva Júnior A, De Oliveira A. Plant-derived Antimalarial Agents: New Leads and Efficient Phytomedicines. Part II. Non-alkaloidal natural products. Molecules. 2009;14(8):3037-72.

48. Khaomek $\mathrm{P}$, Ichino C, Ishiyama A, Sekiguchi H, Namatame M, Ruangrungsi N, et al. In Vitro Antimalarial Activity of Prenylated Flavonoids from Erythrina fusca. J Nat Med. 2008;62(2):21720.

49. Rudrapal M, Chetia D. Plant Flavonoids as Potential Source of Future Antimalarial leads. Syst Rev Pharm. 2017;8(1):13-8.

50. Ziegler HL, Stærk D, Christensen J, Hviid L, Hägerstrand H, Jaroszewskil JW. In vitro
Plasmodium falciparum drug Sensitivity Assay: Inhibition of Parasite Growth by Incorporation of Stomatocytogenic Amphiphiles into the Erythrocyte Membrane. Antimicrob Agents Chemother. 2002;46(5):1441-6.

51. Widyawaruyanti A, Zaini NC, Syafruddin. Mekanisme dan Aktivitas Antimalaria dari Senyawa Flavonoid yang Diisolasi dari Cempedak (Artocarpus champeden). JBP. 2011;13(2):67-77.

52. Nogueira CR, Lopes LMX. Antiplasmodial Natural Products. Molecules. 2011;16(3):214690.

53. Ziegler HL, Franzyk H, Sairafianpour M, Tabatabai M, Tehrani MD, Bagherzadeh K, et al. Erythrocyte Membrane Modifying Agents and the Inhibition of Plasmodium falciparum Growth: Structure-activity Relationships for Betulinic Acid Analogues. Bioorganic Med Chem. 2004;12(1):119-27.

54. Helmi H, Afriyansyah B, Ekasari W. The Effectiveness of Local Plants from Lom and Sawang Ethnics as Antimalarial Medicine. Biosaintifika J Biol Biol Educ. 2016;8(2):193200. 